\title{
Gardner Syndrome with Extra and Intra-Abdominal Desmoid Tumors and Adrenal Involvement: PET/CT Findings
}

\author{
Intra-Abdominal ve Ekstra-Abdominal Dezmoid Tümörler ve Adrenal Tutulumla Birlikte \\ Gardner Sendromu: PET/BT Bulguları
}

\author{
Alshaima Alshammari, Rasha Ashkanani, Saker Alabsi, Mohammed Ghanem \\ Mubarak Al-Kabeer Hospital, Clinic of Nuclear Medicine, Jabriya, Kuwait
}

\begin{abstract}
Gardner syndrome, also known as familial colorectal polyposis, is an autosomal dominant disease and is part of the spectrum of familial adenomatous polyposis (FAP) syndromes. It is characterized by the presence of multiple polyps in the colon together with neoplasms outside the colon. Gardner syndrome is also associated with desmoid tumors in approximately $15 \%$ of affected individuals. Desmoid tumors are rare benign slow-growing neoplasms, arising from connective tissue (musculoaponeurotic fibrous tissue). Due to their locally aggressive nature, the term aggressive fibromatosis have been used to describe these tumors. Seven percent of patients with FAP or its variants may also have adrenal masses, most being benign and asymptomatic. We report the PET/CT of a 42 year old patient who was diagnosed with Gardner syndrome, demonstrating the rare coexistence of the intestinal polyps, extra and intra-abdominal desmoids and adrenal adenoma by PET/CT. In addition, the characteristic cutaneous lesions and osteomas of the skull were also identified.

Key words: Positron emission tomography and computed tomography, Gardner syndrome
\end{abstract}

Conflicts of Interest: The authors reported no conflict of interest related to this article.

\section{Özet}

Ailesel kolorektal polipozis olarak da bilinen Gardner sendromu otozomal dominant bir hastalık olup ailesel adenomatöz polipozis (AAP) spektrumunun bir parçasıdır. Kolonda çok sayıda poliplerle birlikte kolon dışında neoplazmların varlığı ile karakterizedir. Gardner sendromu aynı zamanda, etkilenen bireylerin \%15'inde dezmoid tümörlerle de ilişkilidir. Dezmoid tümörler nadir görülen, benign, yavaş büyüyen neplazmlar olup bağ dokudan (muküloaponevrotik fibröz doku) gelişmektedir. Lokal agresif karakterlerinden dolayı bu tümörleri tanımlamak için agresif fibromatözler terimi kullanılmıştır. AAP veya varyantlarına sahip hastaların \%7'sinde adrenal kitle de bulunmakta olup çoğu benign ve asemptomatiktir. Burada, Gardner sendromu olan 42 yaşında bir hastanın intestinal polip, ekstra- ve intra- abdominal dezmoidler ve adrenal adenomun nadir görülen birlikteliğini gösteren PET/BT sonucunu bildirmekteyiz. Ayrıca, karakteristik kutanöz lezyonlar ve kafatası osteomları da bulunmaktadır.

Anahtar kelimeler: Pozitron emisyon tomografi ve bilgisayarlı tomografi, Gardner sendromu

Çıkar Çatışması: Yazarlar bu makale ile ilgili olarak herhangi bir çıkar çatışması bildirmemiştir.

Address for Correspondence: Alshaima Alshammari MD, Mubarak Al-Kabeer Hospital, Clinic of Nuclear Medicine, Jabriya, Kuwait Phone: (00965) 99674017 E-mail: alshaima_97@hotmail.com Received: 03.05.2013 Accepted: 18.08.2013 


\section{Introduction}

Gardner syndrome, also known as familial colorectal polyposis, is an autosomal dominant disease caused by mutation in the APC gene that is located in chromosome $5 q 21$, and as such is considered part of the spectrum of familial adenomatous polyposis (FAP) syndromes (1). Most patients with Gardner syndrome are female (ratio, 3:1). It is characterized by the presence of multiple polyps in the colon along with neoplasms outside the colon. Polyps can be found in the stomach, duodenum, spleen, kidneys, liver, mesentery, small bowel and in limited cases, have been prescribed in the cerebellum. The extra-colonic tumors may include osteomas of the skull and particularly the jaws, epidermoid cysts, fibromas and sebaceous cysts. Other features of Gardner syndrome that are similar to classic FAP include extra or un-erupted teeth and congenital hypertrophy of the retinal pigment epithelium. The risk of developing colon cancer is significantly high if the colon is not removed. The risk of developing small bowel cancer, pancreatic cancer, papillary thyroid cancer, hepatoblastoma, CNS tumors, stomach cancer, bile duct cancer, or adrenal gland cancer is much less significant (2). Gardner syndrome is also associated with desmoid tumors in approximately $15 \%$ of affected individuals (2).

The estimated risk of developing a desmoid tumor in patients with FAP is $4-20 \%$. In the past, the combination of familial polyposis and desmoid tumors, along with other non-intestinal manifestations, was essential in the definition of Gardner syndrome. It is now recognized that patients with familial polyposis with or without desmoid tumors may have the same genetic abnormality - thus, the name is currently less utilized to describe such an association, and is only used for patients with a proven gene mutation (3).

Desmoid tumors are rare, benign, slowgrowing neoplasms arising from connective tissue (musculoaponeurotic fibrous tissue). Due to their locally aggressive nature, the term aggressive fibromatosis have been used to describe these tumors. They can grow into and destroy adjacent normal tissues, even bones, leading to significant morbidity, and can even be fatal. They do not metastasize distantly throughout the body (4). The estimated incidence in the general population is 2-4 per million people per year. Individuals between the ages of 15 and 60 are most often affected with a slight preponderance in women. Desmoid tumors may occur sporadically or as mentioned previously, in association with (FAP). Desmoid tumors may be classified as extra-abdominal, abdominal wall, or intra-abdominal (the last is more common in patients with FAP) tumors. The extra-abdominal form is rare and superficial desmoids tend to be less aggressive than deep desmoids (abdominal, extra-abdominal, mesenteric) manifesting themselves as a painless or slightly painful mass $(5,6)$. Desmoid tumors may be influenced by external factors, particularly hormones (either from pregnancy or abnormal estrogen levels from contraceptive or hormone replacement pills) (7). Other risk factors for desmoid disease among FAP patients include female gender, a 3' APC mutation, a positive family history and a history of previous abdominal surgery (8). A 3' APC mutation is the most significant risk factor for intra-abdominal desmoid development among FAP patients (9).

Desmoid tumors are surgically removed when possible. An initial alternative is medical therapy with non-steroidal anti-inflammatory drugs, especially for tumors that involve the intestines, blood vessels, nerves or organs. Radiation therapy (RT) is an alternative for patients who cannot tolerate surgery, or can be used in combination with surgery or chemotherapy. RT is often not considered as an option in intra-abdominal tumors. Chemotherapy may be effective in patients with unresectable tumors. Low dose chemotherapeutic agents produce impressive responses, particularly in children. High-dose chemotherapy is usually given for a shorter duration, and is reserved for unresponsive patients or very symptomatic tumors. Hormonotherapy with tyrosine kinase inhibitor imatinib (brand name Gleevec), and anti-fibrotic agents are new alternatives for therapy. Intra-lesional injection of irritating solutions, and radiofrequency ablation may lead to partial response (10).

\section{Case Report}

A 42-year-old male patient was admitted in March 2012, with complaints of epigastric abdominal pain, chronic rectal bleeding and multiple skin lesions. On physical examination a large, hard abdominal mass was palpable, along with anterior chest and left forearm swelling. His blood count values were normal as well as other biochemical investigations, except a slightly low serum potassium level. Tumor markers were also normal. An ultrasound showed a $16 \times 15 \mathrm{~cm}$, hyper to iso-echoic mass in the left upper quadrant and epigastric regions with calcified foci along with areas of cystic degeneration, likely to be rising from the stomach or small bowel, and likely to represent a gastrointestinal stromal tumor (GIST). The computed tomography (CT) of the chest and abdomen showed a large intra-muscular soft tissue lesion, in the right pectoralis muscles extending to the right shoulder with pressure effect but no associated destructive bony lesions. Furthermore, a huge intra-abdominal heterogeneous mass measuring $11 \times 16 \times 19 \mathrm{~cm}$ was identified, which appeared as an exophytic mass originating from the small bowel wall and stretching the mesentery. There were multiple filling defects in the ascending and descending colon and left adrenal gland. The chest mass was reported as a possible desmoid tumor, the abdominal mass was reported as a possible small bowel GIST or a desmoid tumor. A colonoscopy was advised for the evaluation of multiple filling defects in the colon. Colonoscopy revealed hundreds of sessile and pedunculated polyps, between the rectum and the caecum, the largest being $15 \mathrm{~mm}$ in size. This 
pattern was in keeping with FAP, and a tissue biopsy was done to confirm the diagnosis that showed multiple tubular and tubullovillous adenomas with low grade dysplasia.

A magnetic resonance imaging (MRI) was done for the lump in the left forearm above the wrist joint, which revealed a well defined homogenous hypointense lesion on T1 and T2 WI, with few linear areas of hyperintensity on T1, measuring $9 \times 3 \times 2 \mathrm{~cm}$ in size, showing suppression on STIR and FAT SAT WI, and with no enhancement after gadolinium administration. These findings were suggestive of a desmoid tumor. His head CT showed two small sclerotic bony lesions in the sphenoid sinus, and the outer table of the left frontal bone consistent with multiple osteomas. The biopsy of the chest and left forearm mass confirmed the diagnosis of desmoid tumor. The patient was finally diagnosed as Gardner syndrome.

On March 18th 2012, the patient was referred to our nuclear medicine department for PET/CT scan. He was injected with a dose of $525 \mathrm{MBq}$ of F18- fluorodeoxyglucose (FDG), and whole body scan was acquired 60 minute post injection.

The scan images revealed a hypermetabolic large exophytic intra-abdominal mass which appeared to be originating from the small bowel wall and stretching the mesentery, with SUVmax 4.2 (Figure 1). Multiple hypermetabolic focal lesions were seen in the large bowel, the largest in the rectosigmoidal junction with SUVmax 7.9 (Figure 2). The large right infraclavicular soft tissue (Figure 3) and left forearm masses were not FDG avid. Multiple non FDG avid subcutaneous soft tissue nodules were noted in the parasagittal region of the patient Left side of the lower back (Figure 4) and lower limbs likely to represent epidermoid cysts or sebaceous cysts. In addition, mildly FDG avid lesions were also seen in two large left adrenal nodules (Figure 5), SUVmax was 3.0. The right adrenal was

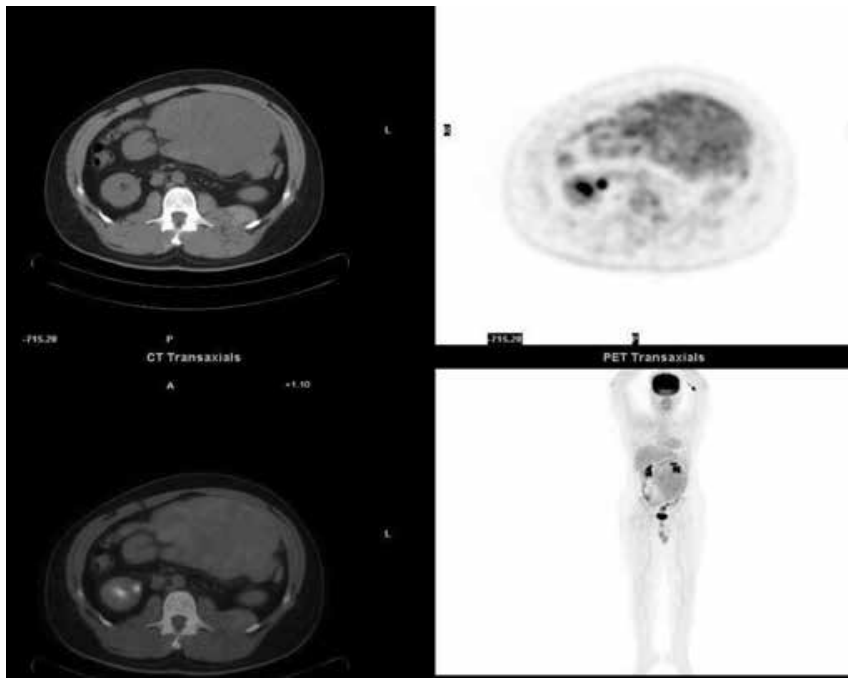

Figure 1. The scan images revealed a hypermetabolic, large, exophytic, intra-abdominal mass which appears to be originating from the small bowel wall and stretching the mesentery enlarged with no FDG uptake. A follow-up MRI showed the adrenal mass to likely represent an adenoma.

\section{Literature Review and Discussion}

Basu and his group studied the uptake pattern of FDG in abdominal desmoid tumors in five patients; three cases of deep musculoskeletal fibromatosis, one of abdominal fibromatosis (abdominal desmoid) associated with familial adenomatous polyposis (Gardner syndrome), and one with both deep musculoskeletal fibromatosis and abdominal desmoid. They noted that the uptake varied from low to
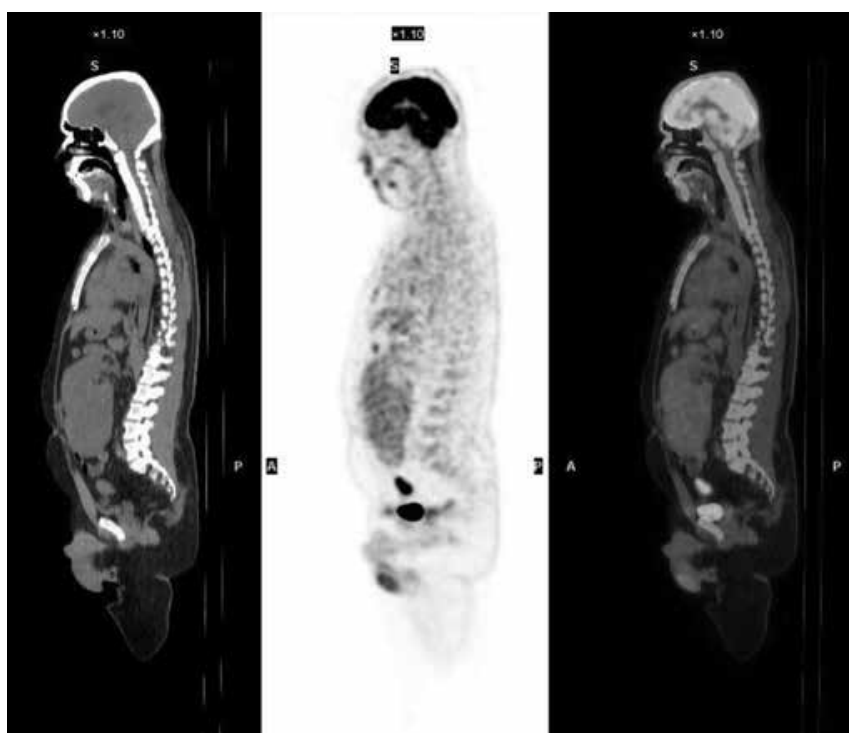

Figure 2. Multiple hypermetabolic focal lesions were seen in the large bowel, the largest in the rectosigmoidal junction

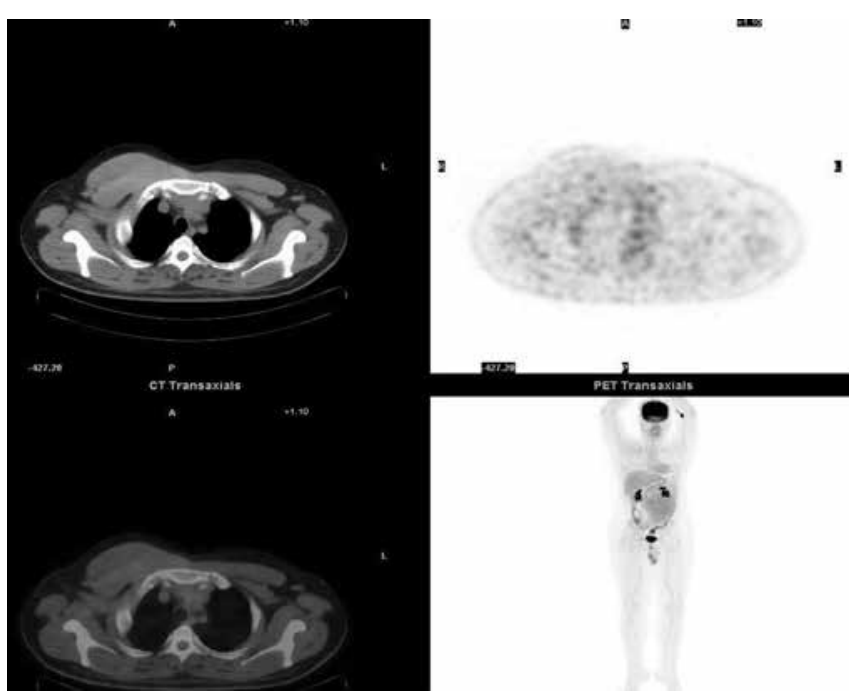

Figure 3. A large non fluorodeoxyglucose avid right infraclavicular soft tissue mass was noted 


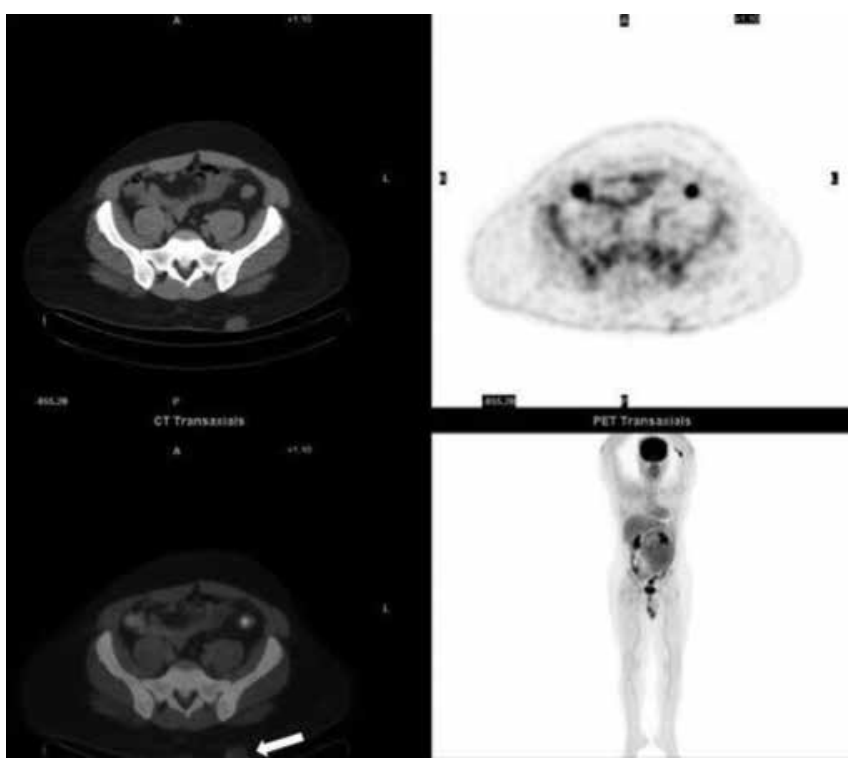

Figure 4. Multiple non fluorodeoxyglucose avid subcutaneous soft tissue nodules were noted in the parasagittal region (arrow head) of the patient back likely to represent epidermoid cysts or sebaceous cysts

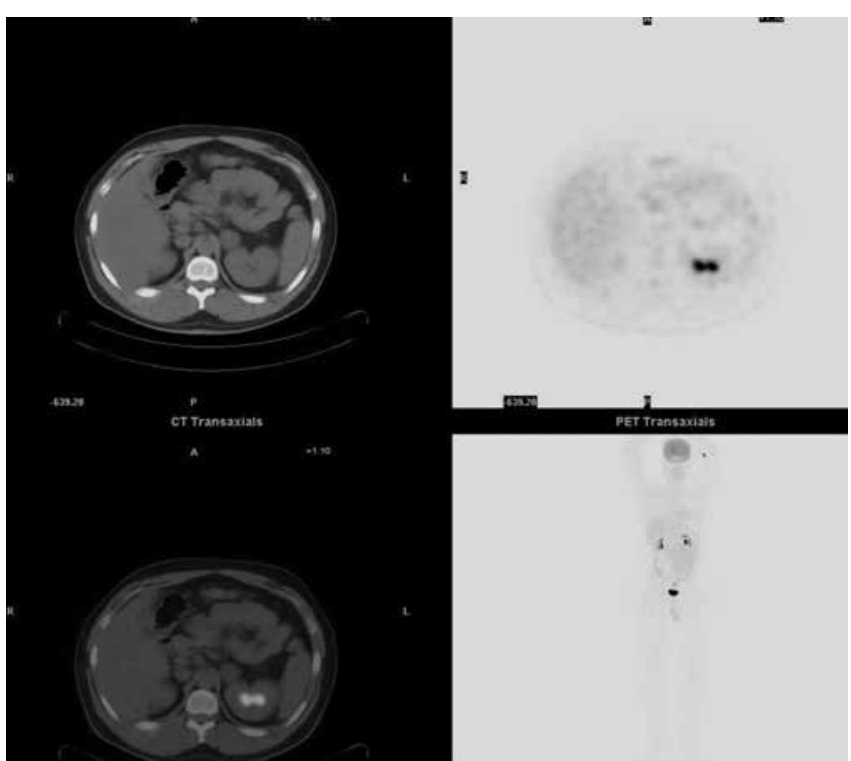

Figure 5. Mildly fluorodeoxyglucose avid lesion was seen in the left adrenal gland

moderate grade with areas of relatively avid FDG uptake with the maximum standardized uptake value (SUVmax) observed up to 4.7, which is close to the value observed in our case in the abdominal desmoid.

They assessed the potential clinical role of FDG-positron emission tomography (PET) in the management of this condition, and found that the reduction in FDG uptake was consistent with histological evidence of reduction in mitosis. They concluded that baseline FDG-PET can serve as a valuable tool in monitoring the effect of systemic pharmacotherapy in those patients. FDG-PET can also be valuable during treatment monitoring, and might be an early indicator of treatment response. Similar to our case, they also observed that these tumors exhibit varying FDG uptake within different parts of the same tumor. They suggested that this may reflect the variations in active cellular tissue and collagen throughout the lesion, and that the areas of higher FDG metabolism are likely to represent more mitotically active areas (11).

Seven percent of patients with FAP or its variants have adrenal masses (12). However, most of these lesions are not functional. Those which are functional usually secrete cortisol $(12,13)$. More aggressive and functional tumors in patients with FAP or its variants have rarely been reported $(12,13)$. This warrants long term follow-up in cases of FAP with adrenal lesions.

\section{References}

1. Tulchinsky H, Keidar A, Strul H, Goldman G, Klausner JM, Rabau M. Extracolonic manifestations of familial adenomatous polyposis after proctocolectomy. Arch Surg 2005;140:159-163.

2. Luba MC, Bangs SA, Mohler AM, Stulberg DL. Common benign skin tumors. Am Fam Physician 2003:67;729-738.

3. Kawashima A, Goldman SM, Fishman EK, Kuhlman JE, Onitsuka $H$, Fukuya T, Masuda K. CT of intraabdominal desmoid tumors: is the tumor different in patients with Gardner's disease? AJR Am J Roentgenol 1994;162:339-342.

4. Enzingen FM, Weiss SW. Soft tissue tumors, 2nd ed. St Louis: Mosby 1988;136-163.

5. Casillas J, Sais GJ, Greve JL, Iparraguirre MC, Morillo G. Imaging of intra- and extraabdominal desmoid tumors. RadioGraphics 1991;11:959-968.

6. Jones IT, Jagelman DG, Fazio WW, Lavery IC, Weakley FL, McGannon E. Desmoid tumors in familial polyposis coli. Ann Surg 1986;204:94-97.

7. Nieuwenhuis $M H$, De Vos Tot Nederveen Cappel W, Botma A, Nagengast FM, Kleibeuker JH, Mathus-Vliegen EM, Dekker E, Dees J, Wijnen J, Vasen HF. Desmoid tumors in a Dutch cohort of patients with familial adenomatous polyposis. Clin Gastroenterol Hepatol 2008;6:215-219.

8. Sinha A, Clark SK. Risk factors predicting desmoid occurrence in patients with familial adenomatous polyposis: a meta-analysis. Colorectal Dis 2010;10:1318-1463.

9. Sinha A, Clark SK. Risk factors predicting intra-abdominal desmoids in familial adenomatous polyposis: a single centre experience. Tech Coloproctol 2010;14:141-146.

10. Rammohan A, Wood JJ. Desmoid tumour of the breast as a manifestation of Gardner's syndrome. Int J Surg Case Rep 2012;3:139-142.

11. BasuS, Nair N, Banavali S. Uptake characteristics of fluorodeoxyglucose (FDG) in deep fibromatosis and abdominal desmoids: potential clinical role of FDG-PET in the management The British Journal of Radiology 2007;80:750-756.

12. Groen E, Roos A, Muntinghe FL, Enting RH, de Vries J, Kleibeuker $\mathrm{JH}$, Witjes M, Links TP, van Beek AP ."Extra-intestinal manifestations of familial adenomatous polyposis," Annals of Surgical Oncology 2008;15:2439-2450.

13. Marchesa P, Fazio V, Church J, McGannon E. "Adrenal masses in patients with familial adenomatous polyposis," Diseases of the Colon and Rectum 1997;40:1023-1028. 